УДК 93

DOI https://doi.org/10.32838/2663-5984/2019/4.2

\title{
Бенчук В.О.
}

Національний університет «Острозька академія»

\section{«РОСІЙСЬКА ВЕСНА» У МАРІУПОЛІ (ЛЮТИЙ - ЧЕРВЕНЬ 2014 РОКУ)}

Стаття присвячена суспільно-політичному протистоянні на Сході Україні, яке через втручання Російської Федерачії переросло у збройний конфлікт. Ці події російські політтехнологи назвали «Російська весна». Вони мало вивчені в науковій літературі. Тому автор намагається на прикладі багатотисячного міста Північного Приазов'я Маріуполя схарактеризувати та проаналізувати події «російської весни» у лютому - червні 2014 року.

Зазначено, що активними учасниками проросійських мітингів були різні маргінальні організаиії та Комуністична партія України. Організовані ними протести були нечисленними, збирали від кількох сотень до півтори тисячі мітингувальників. Це свідчило про відсутність підтримки місиевого населення проросійських виступів або, очевидно, неготовність за них виступати та боротися. Обов'язковим атрибутом усіх їхніх акиї був державний символ Росії-ї̈ прапор.

Значна увага приділена вимогам, які висувають протестувальники. Вони були різні - від повернення експрезидента В. Януковича на свою офіиійну посаду до запрошення Збройних сил Російської Федераиії в місто та приєднання його до Росії як нового суб 'єкта Федерачії. Але після окупаиї Криму російськими військами та провалу політичного проєкту «Новоросія» була сформована мета «Російської весни» - утворення «Донецької Народної Республіки» та «Лугонської Народної Республіки».

Ключові слова: «ДНР», Донбас, збройний конфлікт, КПУ, Маріуполь, мітинг, проросійський pyx.

Постановка проблеми. 20 лютого 2014 р. Російська Федерація (далі - РФ) розпочала неправомірну окупацію української території - півострова Крим, учинивши неспровоковану агресію проти України. Збройна агресія відбулась в умовах суспільно-політичного протистояння в південно-східних областях між прихильниками та противниками революційних змін у державі. У внутрішньополітичні процеси України втрутилось військово-політичне керівництво РФ, оголосивши утворення квазідержавного формування - «Новоросії», політичного проєкту російських політтехнологів. Останні назвали ці події «Російська весна».

Аналіз останніх досліджень і публікацій. Вказана тема у працях вітчизняних і закордонних науковців недостатньо вивчена. Ї̈̈ досліджували, зокрема, В. Головко та Л. Якубова, які у співавторстві в колективній монографії дійшли висновку, що виступи 3 антиукраїнськими лозунгами організували проросійські маргінальні організації, однак вони зійшли нанівець, тому що «суспільні стереотипи та міфи» не знайшли підтвердження в реальності. Але новим поштовхом для активізації проросійського руху став, за визначенням авторів, ««експорт» сепаратизму» РФ, у якому брали участь проросійські агенти впливу, політичні мар- гінали, а також російські громадяни та працівники спецслужб. Їхньою метою була федералізація України для недопущення європейського вектора розвитку держави [1]. В іншій колективній праці, В. Смолія, С. Кульчицького та Л. Якубовой, наголошується, що із квітня 2014 р. російські громадяни, військовики та представники спецслужб значно збільшують свою присутність та участь у вуличних акціях міст Донбасу, що призвело до збройного конфлікту на материковій Україні [33]. Остання теза поширювалася в інших працях цих дослідників [34; 38; 39].

Проросійський рух на Сході України схарактеризував британський та канадський політолог українського походження Т. Кузьо. Дослідник уважає, що його основу складали місцеві іредентисти, які входили до складу різних проросійських та панславіських організацій і проходили вишкіл у російських військових таборах, представники криміналітету, працівники російських спецслужб та «політичні туристи» iз РФ [17]. Окремі аспекти рушійних сил «Російської весни» досліджувались у працях Г. Перепелиці [23], М. Віхрова [4], Д. Казанського [14; 15], Б. Буткевича [2; 3], Є. Шибалова [36], І. Лосєва [13]. Ці історичні процеси досліджують і представники країни-агресора, наприклад, А. Циганков, який 
демонструє «русский взгляд», фальсифікуючи факти та події [35].

Постановка завдання. Мета статті - дослідити й охарактеризувати проросійський рух в українському місті Маріуполі в лютому - червні 2014 p.

Виклад основного матеріалу дослідження. Соціологічне дослідження, проведене Київським міжнародним інститутом соціології у квітні 2014 р., «Думки та погляди жителів південносхідних областей України: квітень 2014» продемонструвало неоднозначну ситуацію на Донбасі щодо подій «Російської весни». На питання «Чи готові Ви вийти на вулицю і підтримати мітинги щодо приєднання Вашого регіону до Росії?» у Донецькій області «Так» відповіли 25,5\%, «Ні» $64,6 \%$, «Важко відповісти» - 8,4\%. Щодо питання «Державний устрій України повинен бути < ..>?», то $10,6 \%$ обрали відповідь «Унітарним - області повинні мати ті права, які мають», «Унітарним, але потрібно провести децентралізацію та розширити права області» - 41,1\%, «Федеративний» $38,4 \%[16]$.

23 лютого 2014 р. $з$ ініціативи Маріупольської громадської організації (далі - ГО) «Искренность» (сфера діяльності якої - благодійна допомога дітям-сиротам, багатодітним сім'ям, дітям війни, спонсором якої останні роки був Маріупольський меткомбінат ім. Ілліча) був організований мітинг [22]. На багатьох присутніх були георгіӥвські стрічки. Спочатку він проходив на Театральній площі, а згодом учасники акції вирушили на площу біля пам'ятника Володимиру Леніну, де зібралися прихильники Майдану. Послідовники Антимайдану - 600 осіб, яких очолювали члени ГО «Искренность», Комуністичної партії України (далі - КПУ) та молодики спортивної зовнішності. Лунали закликали до федералізації України, створення загонів самооборони й озброєння всіх присутніх для [5] «захисту південного сходу України від фашистів» [25, с. 4].

1 березня відбулися відразу два проросійські мітинги - один біля пам'ятника Володимиру Висоцькому, організований членами КПУ, на якому зібралося приблизно 600 осіб, другий - біля міської ради. Лідер маріупольських комуністів В. Дейнес пропонував створити «антифашистський комітет», мета якого - створення громадської ради для контролю міської влади. На ньому поруч із комуністичними прапорами були й російські. Підсумком протесту стало ухвалення резолюції, де вимагали від місцевої влади визначатись щодо «загарбників центральної влади». Інший мітинг, організатором якого була партія «Гражданская солидарность», був більш численний. До нього приєдналися активісти 3 мітингу біля пам'ятника В. Висоцькому. На ньому протестувальники на флагшток адміністративної установи вивісили прапори Союзу Радянських Соціалістичних Республік і Росії, зачитали текст резолюції меру міста Ю. Хотлубею [26, с. 3].

Наступного дня була зібрана позачергова сесія міської ради 3 метою розглянути резолюцію. Біля стін останньої зібралося приблизно 1 тис. проросійських активістів, яких після обіду залишилось не більше 300 [7]. На сесії лідер «Гражданской солидарности» О. Буцко вимагав від місцевої влади не підкорятися новій владі, адже В. Янукович - «єдиний законний Президент України» [32]. В умовах дискусії між різними політичними силами міська рада ухвалила звернення до Верховної Ради України (далі - ВРУ), яке відбиває текст резолюції, а саме:

- відновити чинність Закону України «Про засади державної мовної політики»;

- припинити прояви націоналізму, фашизму та розпалювання міжнаціональної ворожнечі;

- внести зміни до Конституції України щодо децентралізації;

- зробии дієві кроки для налагодження дружніх і добросусідських відносин із РФ, насамперед в економічній і політичній сферах.

На вулиці проросійські протестувальники виступали із закликами «ввести у Приазов'я миротворчі війська братського народу для захисту південно-східного населення від безчинств коричневої чуми» [26, с. 1-3]. Крім того, ними написано лист до президента РФ В. Путіна, який складався 35 пунктів. У ньому російського президента просили «відновити законний конституційний лад», а в разі агресії проти російськомовного населення Маріуполя застосувати Збройні сили РФ [24].

Мітинги продовжувалися 3, 5, 8, 15 березня. Останній був найчисленнішим, на нього зібрались майже 1500 активістів. Організаторами виступили низка громадських організацій та партій, а саме: «Антифашистський комітет», «Народное освободительное движение Украины», «Народ Мариуполя», «Народный комитет Донбасса» та партії «Руський блок України» і КПУ, вони ж були ініціаторами попередніх протестів [11]. Вони вимагали проведення референдуму з метою федералізації України та «курсу на входження у Митний союз і всебічну інтеграцію із братськими народами країн СНД», частина пропонувала увійти до складу РФ, адже там більші, ніж в Україні, зарплати, пенсії та стипендії [27, с. 3]. 
Для стабілізації ситуації в місті, де відбулося суспільно-політичне протистояння між проросійськими активістами та прихильниками єдиної України, влада скликала круглий стіл. На ньому обговорили ситуацію в місті й обмінялися думками щодо подальших кроків. Представники проросійських сил пропонували різне бачення виходу із ситуації. О. Буцкой висунув ідею звернутися до ВРУ з вимогою тимчасово припинити укладання Угоди про асоціацію з Європейським Союзом (далі - СC), поки не проведуть позачергові парламентські вибори та не сформують новий Кабінет Міністрів України (далі - КМУ). Лідер комуністів пропонував ввести у склад виконкому міської влади трьох представників громадськості, які будуть мати право вето. Інший їхній представник Д. Кузьменко закликав надати Донецькій області автономію. Ці й інші пропозиції взяли на опрацювання, щоб винести їх 25 березня на сесії міської ради $[12$, с. 2$]$.

21 березня під стінами міської ради встановлений намет під назвою «Патриоты Мариуполя». У ньому роздавали листівки з написом «Янукович, вернись! Наведи порядок», та запрошували людей на мітинг наступного дня. На акції зібралось понад 1000 активістів, але вперше без російських прапорів, а з радянською символікою. Однак згодом прапори РФ з'явились [8]. Протестувальники заявили, що В. Янукович залишається «єдиним законним Президентом України», та записали до нього відеозвернення, де вимагали від нього «виконати клятву, дану українському народові». Текст звернення читав Д. Кузьменко - заступник керівника ГО «ТОР Маріуполь». Однак лунали заклики до написання звернення і до російського президента В. Путіна, проте ця ідея не мала підтримки серед мітингувальників [28, с. 2].

Наметовий табір збільшувався. У ньому організували збір продуктів, польову кухню й агітацію жителів із метою залучення їх до запланованої акції 25 березня. Його метою була не лише підтримка експрезидента, а й проведення референдуму, децентралізації та вимога припинення кримінальних переслідувань активістів за участь у проросійських мітингах [6]. Запланованої дати відбулось «Народне віче», на якому обрали «народного мера» Маріуполя Д. Кузьменка. Такий крок був зумовлений, за словами мітингувальників, співпрацею місцевої влади 3 «незаконною владою» у Києві, адже, на їхню думку, В. Янукович залишається легітимним президентом [21]. Згідно iз заявою Ради громадських організації Маріуполя, яка об’єднала провідні громадські органі- зації міста, дії проросійських активістів активно підтримувались та контролювались російськими спецслужбами з метою планомірної дестабілізації ситуації в Маріуполі [30, с. 2].

Запланована сесія була перенесена на 28 березня. На ній ухвалено звернення до ВРУ та КМУ, де вкотре раз були віддзеркалені вимоги проросійські вимоги, зокрема - внесення змін до Конституції України щодо децентралізації влади та бюджету, надання російській мові статусу другої державної, ухвалення Закону «Про муніципальну міліцію» тощо [29, с. 1].

Проте мітинги не припинились. 29 березня відбулась чергова акція, на якій було майже тисяча людей. Підтримали їх і працівники двох містоутворювальних комбінатів - ім. Ілліча та «Азовсталь», якими володіє група «Метінвест». Як вони стверджували, керівництво підприємств забороняло їм брати участь у таких акціях під загрозою звільнення [10]. Дії проросійських сил призвели до арешту їх керівників на чолі 3 «народним мером». Це викликало безлад у місті, організований прихильниками останніх. А після проголошення 6 квітня так званої «Донецької Народної Республіки» (далі - «ДНР») у Донецьку в Маріуполі, біля табору «Патриоты Мариуполя» жінки організували мітинг. Основним його гаслом було «Все мужики - на защиту Донецка». Одна партія вже була відправлена, але потрібно було підкріплення, тому сформувався ще один виїзд усіх, хто мав бажання. Дехто пропонував вирушити до кордону в район м. Новоазовськ, адже там нібито знаходяться бійці «Правого сектору». Крім того, присутнім давали бюлетені, які пропонувалося заповнити. У них просили відповісти на два такі запитання: «Ви за приєднання Донецької області до Росії на правах нового суб'єкта РФ?», «Ви за статус Донецької області як автономної у складі Української федеративної держави із двома державними мовами (українською і російською)?» [18].

13 квітня місцеві прихильники «ДНР» захопили міську раду й оголосили Маріуполь територією невизнаної республіки. Сформували нову місцеву владу, відібравши 3 натовпу приблизно 20-30 чоловіків та проголосивши їх депутатами. Останні відразу провели засідання від імені «ДНР», обравши в.о. «народного мера» В. Кукліна [9]. 16 квітня у місті з'явилися перші «зелені чоловічки» у камуфляжній формі, балаклавах та без розпізнавальних знаків. Цього ж дня відбувся штурм в/ч № 3057 НГУ бойовиками, які прикривались проросійськими мітингувальниками. За 
інформацією «Інформаційного спротиву», невідомими у військовій формі були 3 місцевих, які отримали базову військову підготовку в російському таборі та керувались офіцером Головного розвідувального управління Збройних сил РФ. Як згодом прокоментував ці події брат арештованого «народного мера» Маріуполя, місцевих прихильників «ДНР» невідомі люди змусили йти на штурм української військової частини [37].

22 квітня на «сесії» так званої «ДНР» було обговорено питання, яке мало бути в бюлетені на «референдумі». Ухвалено рішення про обговорення лише одного питання - «Чи підтримуєте Ви проголошення суверенної Донецької Народної Республіки з подальшим iї входженням у Митний союз?». Однак передбачалось, якщо люди проголосують проти входження, то «ДНР» у такому разі готова укласти меморандум 3 українською владою про взаємодію. Він мав би складатись iз 12-13 пунктів. Головними його умовами були 6 федералізація України та повна амністія всіх учасників протестних акцій. Для затвердження рішення не вистачало депутатського кворуму, тому через кілька днів обговорили та затвердили питання «Чи підтримуєте Ви акт про державну самостійність Донецької Народної Республіки?» [19].

Місцеві прихильники «ДНР» захопили низку адміністративних установ у місті та готувались до проведення «референдуму». Він відбувся на тлі силового протистояння між українськими військовими та парамілітарними формуваннями «ДНР». Останні дестабілізували ситуацію в місті та влаштували повне беззаконня - погроми, грабунки, стрільбу з автоматичної зброї. Унаслідок організованої ними провокації 9 травня, коли в боротьбі за районне управління міліції постраждали цивільні люди, командування антитерористичної операції вирішило відвести українські війська 3 міста [20, с. 203]. Із-за подій 9 травня мешканці Маріуполя масово пішли на так званий «референдум», налякані недавніми подіями. Явка на нього становила 43,45\%, 3 яких 92,91\% проголосували за суверенітет «ДНР» [31, с. 2]. Результатом «референдуму» стало «визнання» його учасниками «ДНР», однак іiї влада в місті проіснувала не довго. 13 червня Маріуполь звільнено від російсько-окупаційних військ [20, с. 204].

Висновки. Отже, проведене дослідження засвідчило складність та неоднозначність подій «Російської весни» у Маріуполі в новітній історії України. Рушійними силами проросійського руху були низка маргінальних громадських організацій і об'єднань, партії проросійського спрямування, особливу активність серед яких проявила КПУ, та українське населення. Однак, як засвідчила кількість мітингувальників, місцеві мешканці особливо не підтримували їхню мету та дії або, очевидно, не готові були за них виступати та боротися.

Мета проросійського руху була неясна - хтось виступав за децентралізацію та надання російській мові статусу другої державної, другі прагнули приєднання до РФ та запрошували російські війська в місто, інші виступали за надання автономії Донецькій області, а дехто - за суверенність «ДНР». Учасники акції, закладаючи власний сенс у свої дії, через обставини стали заручниками ситуації та виступили колаборантами. Проте коли суспільно-політичне протистояння переросло в силове, унаслідок дій російських диверсійних груп у низці донецьких міст, а проєкт російських політтехнологів «Новоросія» не отримав підтримки серед українського населення, була сформована кінцева мета «Російської весни» - утворення квазідержави «ДНР», контрольованої та підпорядкованої військово-політичному керівництву РФ.

\section{Список літератури:}

1. 25 років незалежності: нариси історії творення нації та держави / Г. Боряк (кер. авт. кол.) та ін. ; НАН України ; Ін-т історії України. Київ : Ніка-Центр, 2016. 796 с.

2. Буткевич Б. Атомізований креатив. Український тиждень. 2014. № № 17-18. С. 10-12.

3. Буткевич Б. Донбас Передчуття війни. Украӥнський тиждень. 2014. № 16. С. 6-7.

4. Віхров М. Дикий Схід. Нарис історії та сьогодення Донбасу. Київ : Темора, 2018. 356 с.

5. В Мариуполе Антимайдан пришел к Ленину поговорить со сторонниками Майдана (дополнено фото). URL: https://www.0629.com.ua/news/481432/v-mariupole-antimajdan-prisel-k-leninu-pogovorit-sostoronnikami-majdana-dopolneno-foto (дата звернення: 14.11.2019).

6. В Мариуполе возле горсовета митингующие разбили палаточный лагерь (фото). URL: https://www.0629.com.ua/news/500536/v-mariupole-vozle-gorsoveta-mitinguusie-razbili-palatocnyj-lager-foto (дата звернення: 14.11.2019).

7. В Мариуполе началась внеочередная сессия городского совета. URL: https://www.0629.com.ua/ news/486586/v-mariupole-nacalas-vneocerednaa-sessia-gorodskogo-soveta (дата звернення: 14.11.2019). 
8. В Мариуполе начался митинг в поддержку Виктора Януковича, к которому в итоге записали обращение (обновляется, фото, видео). URL: https://www.0629.com.ua/news/500220/v-mariupole-nacalsa-mitingv-podderzku-viktora-anukovica-k-kotoromu-v-itoge-zapisali-obrasenie-obnovlaetsa-foto-video (дата звернення: 14.11.2019).

9. В Мариуполе новым «народным мэром» стал Вячеслав Куклин. URL: https://112.ua/obshchestvo/ v-mariupole-novym-narodnym-merom-stal-vyacheslav-kuklin-48990.html (дата звернення: 14.11.2019).

10. В Мариуполе стартовал митинг за референдум (фото, дополнено). URL: https://www.0629.com.ua/ news/505124/v-mariupole-startoval-miting-za-referendum-fotodopolneno (дата звернення: 14.11.2019).

11. Возле горсовета Мариуполя начался митинг за проведение референдума (фото, видео, дополняется). URL: https://www.0629.com.ua/news/495213/vozle-gorsoveta-mariupola-nacalsa-miting-za-provedeniereferenduma-fotovideodopolnaetsa (дата звернення: 14.11.2019).

12. Ильичевец. Город. 2014. № 29 (10726).

13. Лосєв I. Альянс ватніків і фраків. Украӥнський тиждень. 2014. № 35. С. 20-21.

14. Казанський Д. Як КПУ сприяє сепаратизму. Украӥнський тиждень. 2014. № 40. URL: https://tyzhden. ua/Politics/120457 (дата звернення: 13.11.2019).

15. Казанський Д. Хто керує донецьким бунтом? Украӥнський тиждень. 2014. № 21. С. 8-9.

16. Київський міжнародний інститут соціології. Думки та погляди жителів південно-східних областей України: квітень 2014. URL: http://www.kiis.com.ua/?lang=ukr\&cat=reports\&id=302\&page=1 (дата звернення: 17.11.2019).

17. Кузьо Т. Війна Путіна проти України. Революція, націоналізм і криміналітет. Київ, 2018. 560 с.

18. Мариупольские женщины в «лагере патриотов» объявили о мобилизации мужчин (фото). URL: https://www.0629.com.ua/news/510792/mariupolskie-zensiny-v-lagere-patriotov-obavili-o-mobilizacii-muzcinfoto (дата звернення: 14.11.2019).

19. Мариупольцы на референдуме решат судьбу Донецкой республики (видео). URL: https://www.0629. com.ua/news/521031/mariupolcy-na-referendume-resat-sudbu-doneckoj-respubliki-video (дата звернення: 14.11.2019).

20. Марко С. Хроніка гібридної війни. Київ : Альтерпрес, 2016. 236 с.

21. Народное вече выбрало народным мэром Мариуполя Кузьменко (фото, дополнено). URL: https://www.0629.com.ua/news/501931/narodnoe-vece-vybralo-narodnym-merom-mariupola-kuzmenkofotodopolneno (дата звернення: 14.11.2019).

22. ОО «Искренность» отрицает свою причастность к киевскому антимайдану. URL: https://www.0629. com.ua/news/745463/oo-iskrennost-otricaet-svou-pricastnost-k-kievskomu-antimajdanu (дата звернення: 14.11.2019).

23. Перепелиця Г. Україна-Росія: війна в умовах співіснування. Київ : Видавничий дім «Стилос», 2017. 880 с.

24. Письмо Путину, с которым ознакомился мэр Мариуполя, отвезут в Таганрог (фото, документ). URL: https://www.0629.com.ua/news/486742/pismo-putinu-s-kotorym-oznakomilsa-mer-mariupola-otvezut-vtaganrog-foto-dokument (дата звернення: 14.11.2019).

25. Приазовский рабочий. 2014. № 28 (19802).

26. Приазовский рабочий. 2014. № 32 (19806).

27. Приазовский рабочий. 2014. № 38 (19812).

28. Приазовский рабочий. 2014. № 42 (19816).

29. Приазовский рабочий. 2014. № 47 (19821).

30. Приазовский рабочий. 2014. № 48 (19822).

31. Приазовский рабочий. 2014. № 67 (19841).

32. Сегодняшний митинг: чего ожидать мариупольцам? URL: http://mariupolnews.com.ua/news/view/ segodnyashnij-miting-chego-ozhidat-mariupoltsam (дата звернення: 14.11.2019).

33. Смолій В., Кульчицький С., Якубова Л. Донбас і Крим в економічному, суспільно-політичному та етнокультурному просторі України: історичний досвід, модерні виклики, перспективи : аналітична доповідь. Київ : Інститут історії України НАН України, 2016. 616 с.

34. Смолій В., Якубова Л. Історичний контекст формування проекту русский мир та практика його реалізації в Криму й на Донбасі : аналітична записка. Київ, 2018. 144 с.

35. Цыганок А. Донбасс: неоконченная война. Гражданская война на Украине (2014-2016): русский взгляд. Москва, 2016. 680 с.

36. Шибалов Є. «ДНР» зсередини. Короткий лікнеп. Дзеркало тижня. 2014. № 34. URL: https://dt.ua/internal/dnr-zseredini-korotkiy-liknep-_html (дата звернення: 13.11.2019).

37. Штурмом воинской части в Мариуполе руководит российское ГРУ, - Тымчук. URL: https://podrobnosti.ua/971346-shturmom-voinskoj-chasti-v-mariupole-rukovodit-rossijskoe-gru-tymchuk.html (дата звернення: 15.11.2019). 
38. Якубова Л., Головко В., Примаченко Я. «Русский мир» на Донбасі та в Криму: історичні витоки, політична технологія, інструмент агресії : аналітична доповідь. Київ : Інститут історії України, 2018. 227 с.

39. Якубова Л. «Русский мир» в Україні: на краю прірви. Київ : ТОВ «Видавництво «Кліо»», 2018. $384 \mathrm{c}$.

\section{Benchuk V.O. THE "RUSSIAN SPRING” IN MARIUPOL (FEBRUARY - JUNE 2014)}

As a result of the revolutionary changes which were generated by the Maidan, a socio-political confrontation has taken place in the southeastern regions of Ukraine, and due to Russian intervention it has grown into an armed conflict. These vents are still not fully investigated, giving rise to a number of myths in the social and scientific spheres. Therefore in the article, the events of the Russian Spring in February - June 2014 are described and analyzed on the example of the North Azov city Mariupol.

As a result, the author came to the conclusion that the events of the "Russian Spring" in Mariupol evidenced the complexity and ambiguity in the recent history of Ukraine. The driving forces of the pro-Russian movement were a number of marginalized associations, pro-Russian parties, particularly active among the $C P U$ and the Ukrainian population. However, as evidenced by the number of their rallies, the locals were not particularly supportive of their goals and actions, or were not ready for them to stand up and fight.

The purpose of the pro-Russian movement was rather unclear - some were in favor of decentralization and Russian language could have been granted a name of second state language in Ukraine, some were thinking of joining the Russian Federation and invited Russian troops to the city. The others argued for granting autonomy to the Donetsk region, and some of them called for DPR sovereignty. Participants of the action, laying their own sense in these actions, became hostages of the situation due to circumstances and acted as collaborators as a result of the actions of the Russian special services. However, when the socio-political confrontation escalated into a force, as a result of the actions of Russian sabotage groups in a number of Donetsk cities, and the project of Russian political technologists "Novorossiya" did not receive support among the Ukrainian population. The ultimate goal of the "Russian spring” was formed - the formation of the quasi-state „DPR”, controlled and subordinate to the military-political leadership of the Russian Federation.

Key words: armed conflict, Communist Party of Ukraine, "DNR", Donbas, Mariupol, meeting, pro-russian movement. 